OPEN ACCESS

Edited by:

Fuzheng Guo,

University of California, Davis,

United States

Reviewed by:

Feng Mei,

Army Medical University, China

Ben Emery,

Oregon Health and Science

University, United States

${ }^{*}$ Correspondence:

Xianhua Piao

Xianhua.piao@ucsf.edu

Specialty section:

This article was submitted to

Non-Neuronal Cells,

a section of the journal

Frontiers in Cellular Neuroscience

Received: 25 August 2021

Accepted: 11 October 2021

Published: 04 November 2021

Citation:

Motavaf M and Piao X (2021)

Oligodendrocyte Development and Implication in Perinatal White

Matter Injury.

Front. Cell. Neurosci. 15:764486 doi: 10.3389/fncel.2021.764486

\section{Oligodendrocyte Development and Implication in Perinatal White Matter Injury}

\author{
Mahsa Motavaf ${ }^{1}$ and Xianhua Piao ${ }^{2,3,4,5 *}$ \\ ${ }^{1}$ Functional Neurosurgery Research Center, Shohada Tajrish Comprehensive Neurosurgical Center of Excellence, Shahid \\ Beheshti University of Medical Sciences, Tehran, Iran, ${ }^{2}$ Eli and Edythe Broad Center of Regeneration Medicine and Stem \\ Cell Research, University of California, San Francisco, San Francisco, CA, United States, ${ }^{3}$ Newborn Brain Research Institute, \\ University of California, San Francisco, San Francisco, CA, United States, ${ }^{4}$ Weill Institute for Neuroscience, University \\ of California, San Francisco, San Francisco, CA, United States, ${ }^{5}$ Division of Neonatology, Department of Pediatrics, \\ University of California, San Francisco, San Francisco, CA, United States
}

Perinatal white matter injury (WMI) is the most common brain injury in premature infants and can lead to life-long neurological deficits such as cerebral palsy. Preterm birth is typically accompanied by inflammation and hypoxic-ischemic events. Such perinatal insults negatively impact maturation of oligodendrocytes (OLs) and cause myelination failure. At present, no treatment options are clinically available to prevent or cure WMI. Given that arrested OL maturation plays a central role in the etiology of perinatal WMI, an increased interest has emerged regarding the functional restoration of these cells as potential therapeutic strategy. Cell transplantation and promoting endogenous oligodendrocyte function are two potential options to address this major unmet need. In this review, we highlight the underlying pathophysiology of WMI with a specific focus on OL biology and their implication for the development of new therapeutic targets.

Keywords: white matter injury, oligodendrocyte, premature birth, hypoxia-ischemia, myelin

\section{INTRODUCTION}

Preterm birth, defined as being born before 37 weeks of gestation (gw), is associated with significant adverse neurological outcomes. White matter injury (WMI) refers to myelin deficit in the developing white matter. It is the most common non-hemorrhagic neuropathology in preterm infants, especially in those born before 28 gw (Rantakari et al., 2021). WMI is associated with life-long neurological sequelae, such as cerebral palsy (CP), cognitive delay, and severe motor and sensory impairment.

Hypoxic-ischemic injury (HI) and inflammation are two major risk factors leading to WMI (Khwaja and Volpe, 2008; van Tilborg et al., 2018a). Preterm infants spend the first few weeks of their life in neonatal intensive care unit when they are at increased risk for $\mathrm{HI}$ and infection. The incidence of WMI peaks at 23-32 gw, a critical window of OL development (Figure 1). During this period, the dominate oligodendrocyte (OL) lineage cells in the developing white matter are $\mathrm{O}^{+}$premyelinating oligodendrocytes (pmOLs). pmOLs are particularly vulnerable to hypoxic and inflammatory insults (Liu et al., 2013). Limited antioxidant defense mechanisms and high levels of mitochondrial oxygen consumption were proposed as major contributors to their vulnerability (Spaas et al., 2021). 


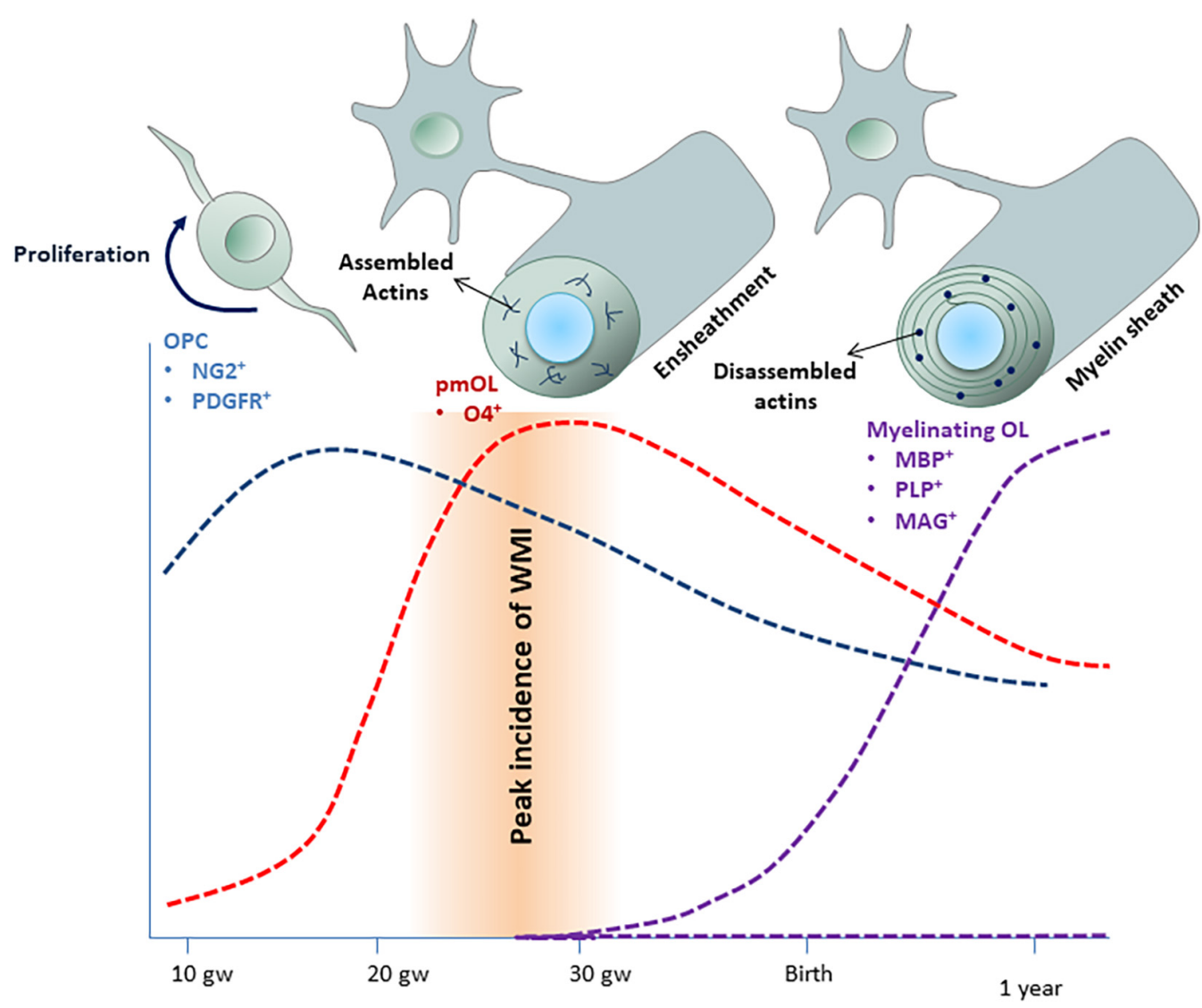

FIGURE 1 | Time-course of human oligodendroglial cell development. Oligodendrocyte precursor cells (OPCs) appear around 9 gw and expanded between 15 and $20 \mathrm{gw}$ (blue area). pmOLs appear as early as $18 \mathrm{gw}$ but peak between 20 and $30 \mathrm{gw}$ (red area). Myelination starts around $25 \mathrm{gw}$ but mostly occurs during the first year of life and continues for several decades (purple area). The incidence of WMl peaks at 23-32 gw, when pmOLs dominate the OL lineage cells population. Actin filament assembly is essential for ensheathment, whereas dynamic actin filament assembly-disassembly drives myelin sheath growth.

Currently, the management of WMI is limited to supportive measure and symptomatic relief. In this review, we summarize the current understanding of oligodendrogenesis and myelination during normal white matter development, as well as the pathophysiology of WMI. Furthermore, we discuss the current state of experimental therapeutic approaches aiming to restore myelination.

\section{OLIGODENDROCYTE DEVELOPMENT AND CENTRAL NERVOUS SYSTEM MYELINATION}

Myelin, the multilayered glial membrane surrounding axons, is paramount to axonal conductivity and health in the jawed vertebrate nervous system. In addition to enable saltatory and fast conduction of action potentials, myelin supplies axons with energy-rich metabolites such as lactate and pyruvate through the monocarboxylate transporters (Pease-Raissi and Chan, 2021). Importantly, myelination facilitates excitatory presynaptic innervation during development (Wang et al., 2018) as well as learning and memory later in life (Wang et al.,
2020). Myelination-enhancing strategies rescues synaptic loss and alleviate cognitive impairments in brains associated white matter pathology (Wang et al., 2018, 2020; Xin and Chan, 2020).

\subsection{Origin of Oligodendrocytes}

In the central nervous system (CNS), myelin is formed by specialized glial cells called OLs, which arise from a lineagerestricted proliferative pool of OL precursor cells (OPCs) (Emery, 2010; van Tilborg et al., 2018b; Elbaz and Popko, 2019). OPCs are derived from neural stem cells (NSCs) in three distinct waves (Kessaris et al., 2006; Rowitch and Kriegstein, 2010). In murine, the initial wave of OPCs is generated from NK2 Homeobox 1 (Nkx2.1)-expressing precursor cells in the medial ganglionic eminence (MGE) and anterior entopeduncular (AEP) regions of ventral telencephalon at embryonic day 12.5 (E12.5) (Kessaris et al., 2006). The second wave emanates from GS homeobox 2 $(\mathrm{Gsh} 2)^{+}$precursors in the lateral ganglionic eminence (LGE) at $\sim$ E15.5 (Kessaris et al., 2006; Chapman et al., 2013). The third wave of OPCs is generated from Empty spiracles homeobox 1 $(\mathrm{Emx} 1)^{+}$precursor cells in the cortex around birth (Kessaris et al., 2006); this last wave of OPCs makes up most of OLs in postnatal life. Recent report showed that a subpopulation 
of first-wave OPCs survives and forms functional cell clusters (Orduz et al., 2019), although biological significance of this finding remains elusive.

In humans, early platelet-derived growth factor receptor $\alpha^{+}$ $\left(\mathrm{PDGFR} \alpha^{+)}\right.$OPCs emerge in the forebrain at around $10 \mathrm{gw}$ and distribute throughout the developing cerebral cortex during the next few weeks. However, a higher number of OPCs appears only around $15 \mathrm{gw}$, when they are most numerous in the ganglionic eminences and in the cortical ventricular zone/subventricular zone (Jakovcevski et al., 2009). One characteristic feature of developing human brain is the presence of an enlarged cortical germinal zone called the outer subventricular zone (OSVZ) where outer radial glia (oRG) reside. Although it was originally proposed to exclusively produce neurons, there is compelling evidence indicating that oRG are sources of OLs in later stages of prenatal development (Rash et al., 2019; Huang et al., 2020).

\subsection{OL Precursor Cells Migration}

OPCs migrate to their designated locations under the guidance of a wide variety of mediators, including extracellular chemotropic cues, secreted molecules, and neuronal activity (Simpson and Armstrong, 1999; van Tilborg et al., 2018b; Baydyuk et al., 2020). For instance, glutamate, the main excitatory neurotransmitter released by excitatory neurons, is a putative chemoattractant and stimulates the migration of OPCs through mechanisms that involve AMPA receptor (Mangin et al., 2012). Additionally, spatial gradients of bone morphogenic proteins (BMPs), Sonic hedgehog (Shh), and Wnt proteins determine the direction of migrating OPCs. Remarkably, OPCs use blood vessels as migratory scaffolds to reach their destination in developing CNS by crawling along and/or jumping between vessels (Kurachi et al., 2016; Tsai et al., 2016). Wnt-medicated activation of chemokine receptor CXCR4 in OPCs enables their attraction to the blood vessels presumably via the endothelial-expressed CXCR4 ligand SDF1 (CXCL12) (Tsai et al., 2016).

\subsection{Oligodendrocyte Proliferation and Differentiation}

Once reached to their destined location, OPCs start to proliferate to populate the entire CNS (Hughes et al., 2013). The expansion of OPCs depends on multiple growth factors and motogenic cues, including PDGF, fibroblast growth factor2 (FGF-2) and insulin-like growth factor-1 (IGF-1). A small population of $\mathrm{PDGFR} \alpha+{ }^{+} / \mathrm{NG}^{+}{ }^{+} \mathrm{OPCs}$ remains as precursor cells into adulthood, constituting $\sim 5 \%$ of total adult CNS cells. These OPCs also display responsiveness to local CNS injury and differentiate into remyelinating OLs (Dawson et al., 2003; Franklin and Ffrench-Constant, 2008). The majority of OPCs differentiate into mature myelinating OLs through a gradual transition from a proliferative state to an elaboration of cell processes. The timing of OL differentiation is tightly regulated both by cell-intrinsic mechanisms and the extrinsic microenvironment.

OPCs begin to differentiate into pmOLs by losing the progenitor markers (PDGFR $\alpha$ ), acquiring a larger cell body, and extending their processes. pmOLs are $\mathrm{O}^{+}$highly ramified cells that extend their processes to ensheathe axons (Zuchero et al., 2015). The establishment of this glial-axon interaction is a critical point in OL differentiation and mediates target-dependent OLs survival.

Following establishment of primary glial-axon interaction, pmOLs differentiate into mature OLs that are characterized by the expression of galactocerebroside (GalC)/O1 and myelin proteins, such as myelin oligodendrocyte glycoprotein (MOG), myelin basic protein (MBP), myelin associated glycoprotein (MAG), and transmembrane protein proteolipid protein (PLP).

Several transcription factors are involved in the regulation of OL lineage differentiation, among which helix-loop-helix (HLH) family members have been extensively studied. Olig2 acts as a central node to which many pathways converge to drive oligodendrogenesis and maturation (Lu et al., 2002; Ligon et al., 2006). For instance, Olig2 directly induces the expression of SRY-box 10 (SOX10), a well-established regulator involved in OL terminal differentiation and myelin formation. Interaction of SOX10 with several genes such as myelin regulatory factor (MYRF) is critical for full differentiation of OLs. Once induced, MYRF mediates the progression of pmOLs to a mature myelinating state. CF7L2 (Zhao et al., 2016), CHD7 (He et al., 2016), ZFP24 (Elbaz et al., 2018), Hes5, NKX2.2, and NFATC2 are among other factors that cooperate with SOX10 to mediate OL differentiation.

Epigenetic mechanisms including DNA methylation, histone modification, and regulatory non-coding RNAs play permissive roles in OL biogenesis (Tiane et al., 2019; Berry et al., 2020). Histone modifications have been shown to be broadly involved in OPC differentiation (Marin-Husstege et al., 2002; Lyssiotis et al., 2007; Chen et al., 2011; Gregath and Lu, 2018; He et al., 2018). Pharmacological inhibition of histone deacetylases (HDACs), the enzyme family responsible for the removal of acetyl-groups from histones, is showed to be associated with a decrease in OL maturation and differentiation (Marin-Husstege et al., 2002). HDAC inhibition reverses the fate of committed OPCs toward NSC state, suggesting their crucial role during OL development (Lyssiotis et al., 2007).

\subsection{Central Nervous System Myelination}

Once physical interactions between OL and axon occur, the initial layers of myelin rapidly wrap around the axons. Simultaneously, the myelin sheath extends longitudinally along the axon and the myelin membrane layers compact their cytoplasm to form mature myelin. During the myelin sheath growth, actin filaments turnover is the driving force by regulating repetitive cycles of leading edge protrusion and spreading (Nawaz et al., 2015). An individual OL has the capacity to myelinate up to 50 axons, depending on their location within the CNS (Sobottka et al., 2011).

To date, two distinct modes of myelination-axonal activitydependent vs. independent-have been proposed (Pease-Raissi and Chan, 2021). In activity-dependent myelination, axonal electrical activity and molecular cues such as growth factors and neurotransmitters govern myelination. Both molecular cascades of synaptic and non-synaptic neurotransmission are involved in activity-regulated myelination and remodeling of existing 
myelin (Almeida et al., 2021). Blocking vesicular mediated neurotransmitter release by tetanus neurotoxin as well as attenuation of neuronal activity reduces percentage of myelinated axons (Suárez et al., 2014; Hines et al., 2015; Koudelka et al., 2016). Furthermore, optogenetic or chemogenetic stimulation of neuronal firing elicits oligodendrogenesis and myelination along the corresponding axons (Gibson et al., 2014; Mitew et al., 2018). Activity-independent myelination is driven and regulated by other factors, including locally secreted factors and axonal diameter (Lee et al., 2013; Bechler et al., 2015).

\section{PATHOPHYSIOLOGY OF WHITE MATTER INJURY}

WMI was historically named as periventricular leukomalacia (PVL) (Volpe, 2017). Histologically, PVL begins with focal coagulation necrosis in periventricular white matter and microglial infiltration within hours after the primary insult. This is followed by astrocytic activation several days later, which eventually leads to complete loss of all cellular elements in necrotic areas and cavitation after about 2 weeks (Volpe, 2003, 2017; Hamrick et al., 2004). In severe cases, PVL necrotic foci range from about $1-6 \mathrm{~mm}$ in diameter. They can extend into the cerebral cortex and occasionally the subcortical white matter (Back, 2017).

Since 1980's, the presentation of WMI has changed from cystic PVL to milder diffuse WMI (dWMI), thanks to the advancement of medical technology and improved clinical management of premature babies (Back, 2017; van Tilborg et al., 2018b). Magnetic resonance imaging (MRI) and head ultrasound are used to diagnose WMI. Qualitative abnormalities in WMI, including signal abnormalities in the white matter, ventriculomegaly, and thinning of the corpus callosum are better visualized by MRI (Riddle et al., 2011). The extent and patterns of myelination abnormalities can be variable. Severity and duration of insult as well as the stage of brain maturation likely play a pivotal role in the severity and extent of the WMI (Sosunov et al., 2021).

Preterm birth coincides with the initiation of oligodendrocyte lineage development (Salmaso et al., 2014). During the window of 24-32 gw, the majority of OL lineage cells are early OPCs $\left(\mathrm{NG}^{+} / \mathrm{O}^{-}\right)$and pmOLs $\left(\mathrm{O}^{+}{ }^{+}, \mathrm{O}^{-}\right)$(Craig et al., 2003; Volpe et al., 2011). pmOLs are particularly vulnerable to insults such as hypoxia and inflammation (Back et al., 1998). Anatomically and functionally immature cerebral vasculature and blood flow autoregulation mechanism contribute to the development of WMI. Furthermore, developmental delay in the expression of antioxidant enzymes in pmOLs is suggested to predispose this specific stage of OL lineage cells to dysfunction or loss (Folkerth et al., 2004; Khwaja and Volpe, 2008).

Examination of human postmortem brains of WMI has revealed dynamic changes in OL lineage cells. In acute lesions, a significant depletion of $\mathrm{O}_{4}^{+}$cells was observed with degenerating $\mathrm{O}^{+}$cells in the core and intact $\mathrm{O}^{+}$cells in more superficial zones of the lesions (Back et al., 2005). In subacute injuries, a regenerative response was seen resulting in an expansion of OL progenitor's pool (Segovia et al., 2008) as well as the total number of OL lineage cells measured as increased Olig2 ${ }^{+}$cell density. Importantly, a significant increase in Olig2 ${ }^{+}$cell density was observed within and immediately adjacent to the necrotic foci but not in the distal areas to the lesions (Billiards et al., 2008; Buser et al., 2012). However, these newly generated progenitors fail to differentiate into mature myelinating OLs (Back and Volpe, 1997; Back et al., 1998, 2002; Billiards et al., 2008; Back, 2017; Sosunov et al., 2021).

The impaired myelination despite the presence of normal or even increased number of Olig2 ${ }^{+}$cells may also in part due to impaired axonal-OL signaling. Indeed, Billiards et al. (2008) showed that significant numbers of OLs express MBP directly in the perikaryon, rather than on the processes, in WMI areas. Dysregulation of MBP mRNA trafficking and/or disruption of oligodendroglial-axonal interaction could be underlying mechanism in failure of myelin sheath formation (Billiards et al., 2008).

Activated astrocytes and microglia contribute to dWMI (Riddle et al., 2011; Buser et al., 2012), as they play both beneficial and detrimental roles in oligodendrogenesis and myelination (Matejuk and Ransohoff, 2020). For instance, STAT3-mediated reactive astrocytes protect myelin development against neuroinflammation by restricting the aberrant expression of microglial TGF $\beta$-1, an inhibitory factor for OL maturation (Nobuta et al., 2012). In contrast, production of several astrocyte-derived factors (e.g., BMPs, endothelin-1, Jagged1) as well as high molecular weight hyaluronan product, have been shown to inhibit OPC differentiation and myelination (Traiffort et al., 2020). Reactive microglia could disrupt proliferation and differentiation of pmOLs through proinflammatory cytokines, such as tumor necrosis factor alpha (TNF $\alpha)$, interleukin (IL) $1 \beta$, IL2, and IL17 (Haynes et al., 2003; Steelman and Li, 2011).

\section{ENHANCING OLIGODENDROCYTES MYELINATION AS THERAPEUTIC STRATEGIES AGAINST WHITE MATTER INJURY}

\subsection{Cell-Based Therapy}

Most of our knowledge in restoring CNS myelination with exogenous cells came from preclinical and clinical studies in congenital hypomyelination disorders. Pelizaeus-Merzbacher disease (PMD; OMIM312080) being an exemplar disease for cellbased therapy using various cell sources. PMD is an X-linked disorder caused by mutation in the proteolipid protein-1 (PLP1) gene. It is a progressive congenital disorder of myelin formation, which results in severe neurological disability. There is no effective treatment to date. An open label phase I clinical trial with allogenic human NSCs transplantation was conducted in four individuals with PMD (ClinicalTrials.gov NCT01005004 and NCT01391637) (Gupta et al., 2012, 2019). This study showed a favorable safety profile, long-lasting cell engraftment, and donorderived myelination (Gupta et al., 2012). At the 2-year posttransplantation follow up, MRI and diffusion tensor imaging (DTI) showed a spectrum of differences between subjects. 
However, these changes became insignificant at 5-year followup (Gupta et al., 2019). On the other hand, the development of donor-specific HLA alloantibodies was detected in two of the four transplanted individuals, suggesting the importance of longterm immunological monitoring (Gupta et al., 2019). The lessons learned from this clinical trial are invaluable for the use of cellbased therapies in demyelinating disease conditions in humans.

In preclinical animal models of hypomyelination disorders, OPCs, NSCs, glial progenitor cells (GPCs), human amnion epithelial cells (hAECs), human umbilical cord blood cells (UCBC), and mesenchymal stem cells (MSCs) have showed beneficial effects in re-establishing myelination and/or function (Potter et al., 2011; Goldman, 2016; Goldman et al., 2021; Table 1). The results from limited human clinical trials have also yielded encouraging results in terms of feasibility, long-term safety, and the therapeutic effect of cell therapy in childhood leukodystrophies and cerebral palsy (Table 2; Wang S. et al., 2013; Goldman, 2017).

Despite significant progress, there are major concerns regarding the use of therapeutic cell-based approaches in humans, particularly in non-fatal disorders. The report of tumors developing several years after human fetal brain-derived cell transplantation has heightened anxiety about the potential for neoplasia (Amariglio et al., 2009), in addition to concerns regarding requirements for long-term immunosuppression. Further research is needed to determine the best cell source for these therapeutic approaches.

The goal of cell-based therapy for WMI varies. Some sought to directly protect myelinating cells through immunomodulation/trophic supports and others to functionally replace the damaged cells (Ruff et al., 2013; Li et al., 2018; Rumajogee et al., 2018). In reality, it is likely that transplanted cells exert their beneficial effects through both modes of action. Transplanted OPCs and GPCs in neonatal WMI animal model were able to effectively differentiate into differentiation into OL phenotype. These OLs showed long-term survival (at 2 months post-transplantation) and improved myelination (Porambo et al., 2015; Ogawa et al., 2020).

As inflammation and cellular degeneration play a major role in pathological cascade of WMI, UCBCs with established immunomodulatory, anti-apoptotic, and neurotrophic properties are a promising autologous cell source for WMI cell therapy. Indeed, a number of preclinical and clinical studies have demonstrated that UCBC administration protects white matter development via prevention of OLs loss, restoration of pmOLs maturation, and exhibition of anti-inflammatory and antioxidant functions (Li et al., 2016; Paton et al., 2018; Ren et al., 2020). To date, more than 20 clinical trials for $C P$ treatment using UCB have been registered from clinicaltrials.gov (Table 2).

Cell delivery route influences the engraftment, migration, and distribution of transplanted cells. Intravenous (IV) transplantation is a less invasive method (Min et al., 2013; Cotten et al., 2014; Kang et al., 2015; Sun et al., 2017). However, a number of studies report pulmonary embolisms and accumulation of transplanted cells in undesired peripheral organs (Steiner et al., 2012; Jung et al., 2013; Wu Z. et al., 2017). Other more direct routes of transplantation are intrathecal (IT) and intra-cerebral
(IC) (Zali et al., 2015; Nguyen et al., 2017; Thanh et al., 2019). The complexity of brain structure and variable localizations of WMI likely influence the selection of proper transplantation route (Henriques et al., 2019). Further preclinical and clinical studies are needed for the development of optimal administration of cell-based therapy.

\subsection{Targeting Endogenous Oligodendrocytes}

Loss of pmOLs during the acute phase of WMI is followed by a significant increase in these cells, suggesting that OPC deficit may not be the major cause of pathology later in life. Instead, dysregulation of pmOL maturation may be the main mechanism underlying neurologic disability in preterm infants (Buser et al., 2012). Thus, therapeutic enhancement of endogenous oligodendrogenesis and myelination is another promising WMI therapeutic strategy. This can be achieved by either testing known regulators of OL development or high throughput screening (Cayre et al., 2021; Table 3).

\subsubsection{Testing Known Regulators}

Several pathways have been explored for their efficacy in promoting developmental myelin formation in animal models (Table 3), a number of which advanced to human studies. The first is IGF-1, which serves as a major regulator of the proliferation and development of OL lineage (Mason et al., 2003; Cui and Almazan, 2007). IGF-1 was protective in preclinical models of WMI (Guan et al., 2001; Cao et al., 2003; Lin et al., 2009; Cai et al., 2011). Furthermore, there is a positive association between postnatal serum IGF-1 concentration, head circumference, brain volume measures, and developmental scores at 2 years of age (Hansen-Pupp et al., 2011). Clinical trials with IGF-1- binding protein 3 in preterm neonates with a focus on preventing retinopathy of prematurity demonstrated safety profile (ClinicalTrials.gov NCT01096784). Further studies are needed to explore the potential neuroprotective effects of IGF-1 with respect to dWMI (Ley et al., 2013).

Erythropoietin (EPO), originally recognized for its role in erythropoiesis, has also been extensively studied in neurological conditioned (Shingo et al., 2001; Wang et al., 2004; Sola et al., 2005; Iwai et al., 2010). EPO receptors (EPOR) are present in all stages of OL lineage cells. Coordinated expression of EPO and its receptor during CNS development is crucial for the survival of OLs (Ruscher et al., 2002; Knabe et al., 2004; Fan et al., 2011; Kako et al., 2012). Notably, prenatal HI injury disrupts this regulated coordination in ischemia-vulnerable immature OLs, predisposing OLs to apoptosis (Mazur et al., 2010). Thus, administration of EPO provides a potential opportunity to optimize the survival of cells that express EPOR, including OL lineage cells. Indeed, postnatal administration of recombinant human EPO (rhEPO) in animal model of WMI was shown to rescue pmOLs from glutamate-induced excitotoxicity, enhance OL function, promote myelin formation, and improve motor skills (Mazur et al., 2010; Liu et al., 2011; Jantzie et al., 2013). Unfortunately, despite the early encouraging results from human clinical trial (Leuchter et al., 2014; Fauchère et al., 2015; O'Gorman et al., 2015), follow-up study failed to show significant 
TABLE 1 | Preclinical experiments on cell therapy strategies to restore myelination.

\begin{tabular}{|c|c|c|c|c|}
\hline Cell type/source & WMI model & Graft region & Findings & References \\
\hline GPCs/fetal human & PNDO Shiverer mice & $\begin{array}{l}\text { CC and cerebellar } \\
\text { peduncle }\end{array}$ & $\begin{array}{l}\text { Improved survival } \\
\text { Improved neurological function } \\
\text { Functional and progressive donor-derived } \\
\text { myelination } \\
\text { Formation of normal nodes of Ranvier and } \\
\text { transcallosal conduction velocities }\end{array}$ & Windrem et al., 2008 \\
\hline iPSC-derived OPCs/human & PNDO Shiverer mice & $\mathrm{CC}$ & $\begin{array}{l}\text { Improved survival } \\
\text { Functional and progressive donor-derived } \\
\text { myelination }\end{array}$ & Wang S. et al., 2013 \\
\hline UCBCs/human & $\begin{array}{l}0.65 \mathrm{gw} \text { fetal } \\
\text { sheep/LPS }\end{array}$ & IV & $\begin{array}{l}\text { Attenuation of inflammation } \\
\text { Restoration of pmOLs maturation } \\
\text { Attenuation of OL death and inflammation } \\
\text { Protection of normal white matter development }\end{array}$ & Paton et al., 2018 \\
\hline Allogeneic UCBCs/fetal sheep & $0.7 \mathrm{gw}$ fetal sheep/HI & IV & $\begin{array}{l}\text { Attenuation of inflammation and oxidative stress } \\
\text { Prevention of OLs loss and Hypomyelination }\end{array}$ & Li et al., 2016 \\
\hline $\begin{array}{l}\text { Allogeneic UCBCs-derived } \\
\text { MSCs }\end{array}$ & $0.7 \mathrm{gw}$ fetal sheep/HI & IV & $\begin{array}{l}\text { Attenuation of inflammation } \\
\text { Maintaining OLs development } \\
\text { Protection against hypomyelination }\end{array}$ & Li et al., 2018 \\
\hline $\begin{array}{l}\text { mESCs derived-olig2 }{ }^{+} \\
\text {cells/Mouse }\end{array}$ & PND3 rat pups/HI & Left LV & $\begin{array}{l}\text { Enhanced myelination } \\
\text { Neuroprotective effects } \\
\text { Improved neurobehavioral performance }\end{array}$ & Chen et al., 2015 \\
\hline $\begin{array}{l}\text { GRP cells from embryonic } \\
\text { spinal cord/Mouse }\end{array}$ & PND5 mice pups/HI & CC & $\begin{array}{l}\text { Reduced long-term survival of GRP cells in WMI } \\
\text { model } \\
\text { Enhanced myelination } \\
\text { Improved neurobehavioral performance }\end{array}$ & Porambo et al., 2015 \\
\hline $\begin{array}{l}\text { Primary NSCs-derived } \\
\text { OPCs/second trimester fetal } \\
\text { brain tissue }\end{array}$ & PND3 rat pups/HI & $\begin{array}{l}\text { right LV or white } \\
\text { matter }\end{array}$ & $\begin{array}{l}\text { Enhanced myelination } \\
\text { Reduced structural damage } \\
\text { Improved neurobehavioral performance }\end{array}$ & Wu C. J. et al., 2017 \\
\hline $\begin{array}{l}\text { Primary NSCs-derived } \\
\text { OPCs/second trimester fetal } \\
\text { brain tissue }\end{array}$ & PND7 rat pups/HI & CV & $\begin{array}{l}\text { Attenuation of myelin loss } \\
\text { Improved neurobehavioral performance }\end{array}$ & Kim et al., 2018 \\
\hline Primary NSCs/mice embryos & $\begin{array}{l}\text { In utero mice } \\
\text { embryo/LPS }\end{array}$ & LV & $\begin{array}{l}\text { Alleviated inflammation and gliosis } \\
\text { Enhanced myelination in the offspring } \\
\text { periventricular region }\end{array}$ & $\begin{array}{l}\text { Borhani-Haghighi et al., } \\
2019\end{array}$ \\
\hline
\end{tabular}

PND, Postnatal Day; CC, Corpus Callosum; LV, Lateral Ventricle; CV, Cerebral Ventricle.

differences in neurodevelopmental outcomes or death (Juul et al., 2020) (ClinicalTrials.gov NCT00413946 and NCT01378273).

\subsubsection{High-Throughput Screening and Drug Repurposing}

High-throughput screening (HTS) platform allows for the identification of approved compounds for repurposing therapy as well as drug discovery (Eleuteri et al., 2017; Manousi et al., 2021). Indeed, screenings for pharmaceutical compounds that promote myelination have revealed several modulators for $G$ proteincoupled receptor (GPCRs) that are major pharmacological targets for myelin-related diseases (Table 3; Mei et al., 2016; Mogha et al., 2016; Folts et al., 2019).

For instance, HAMI3379, initially developed as a cysteinylleukotriene CysLT2 antagonist to treat cardiovascular and inflammatory disorders (Wunder et al., 2010), has the property to enhance OL maturation via antagonizing GPR17 (Merten et al.,
2018). Gpr17, which is abundant in pmOLs and undetectable in mature OLs, is a key regulator of OL differentiation.

GPR56/ADGRG1 is an emerging member of the GPCR family with considerable therapeutic potential in neurodevelopmental disorders (Folts et al., 2019). While this multifunctional GPCR is expressed in OPCs, microglia, astrocytes and neurons, cell autonomous function of OPC-specific ADGRG1 is crucial for proper myelination. Strategies to modulate this interaction provide a potential pharmaceutical target for WMI. Indeed, HTS approach targeting GPR56 has revealed 3- $\alpha$ acetoxydihydrodeoxygedunin (3- $\alpha$-DOG) and monobodies as GPR56 partial agonists (Stoveken et al., 2018; Zhu et al., 2019; Salzman et al., 2020). Further work is needed to determine their druggable property for WMI.

Fingolimod (FTY720), the first oral drug approved for the treatment of relapsing remitting multiple sclerosis (RRMS), is a functional modulator of Sphingosine 1-phosphate receptor 
TABLE 2 | Clinical trials of cells therapy for infants and children with CP and childhood leukodystrophies.

\begin{tabular}{|c|c|c|c|c|c|c|c|c|}
\hline Condition & Identifier & Phase/masking & Cell type & Size & Age & Route & Outcomes & References \\
\hline \multirow[t]{6}{*}{$\mathrm{CP}$} & $\begin{array}{l}\text { NCT01404663 } \\
\text { NCT01763255 }\end{array}$ & $\begin{array}{l}\text { I/Open Label } \\
\text { I,II/Open Label }\end{array}$ & $\begin{array}{l}\text { Autologous } \\
\text { BM- CD133+ }\end{array}$ & $\begin{array}{c}12 \\
8\end{array}$ & $4-12 y$ & $\mathrm{IT}$ & $\begin{array}{l}\text { Improved motor and cognitive } \\
\text { functions }\end{array}$ & Zali et al., 2015 \\
\hline & $\begin{array}{l}\text { NCT03123562 } \\
\text { NCT02569775 }\end{array}$ & II/Open Label & $\begin{array}{l}\text { Autologous } \\
\text { BMMC }\end{array}$ & $\begin{array}{l}25 \\
40\end{array}$ & $2-15$ y & $\mathrm{IT}$ & $\begin{array}{l}\text { Improved gross motor function } \\
\text { and muscle tone }\end{array}$ & $\begin{array}{l}\text { Nguyen et al., } \\
\text { 2017; Thanh } \\
\text { et al., } 2019\end{array}$ \\
\hline & NCT01147653 & ॥/Quadruple & $\begin{array}{l}\text { Autologous } \\
\text { UCBC }\end{array}$ & 63 & $1-6 y$ & IV & $\begin{array}{l}\text { Improved brain connectivity } \\
\text { and gross motor function }\end{array}$ & Sun et al., 2017 \\
\hline & NCT01193660 & NA/Quadruple & $\begin{array}{l}\text { Allogeneic } \\
\text { UCBC } \\
+ \text { recombinant } \\
\text { hEPO }\end{array}$ & 105 & $10 m-10$ & IV & Improved motor and cognitive & Min et al., 2013 \\
\hline & NCT01528436 & ॥/Quadruple & $\begin{array}{l}\text { Allogeneic } \\
\text { UCBC }\end{array}$ & 37 & $6 \mathrm{~m}-20 \mathrm{y}$ & IV & $\begin{array}{l}\text { Improved muscle strength } \\
\text { and gross motor performance }\end{array}$ & $\begin{array}{l}\text { Kang et al., } \\
2015\end{array}$ \\
\hline & NCT01978821 & I/Open label & $\begin{array}{l}\text { Autologous } \\
\text { BM-MSC }\end{array}$ & 52 & $6 \mathrm{~m}-15$ y & $I T+I V$ & Improved gross motor function & $\begin{array}{l}\text { Wang X. et al., } \\
2013\end{array}$ \\
\hline PMD & $\begin{array}{l}\text { NCT01005004 } \\
\text { NCT01391637 }\end{array}$ & I/Open label & $\begin{array}{l}\text { Allogeneic } \\
\text { HuCNS-SCs }\end{array}$ & 4 & $6 \mathrm{~m}-5 \mathrm{y}$ & FLWM & $\begin{array}{l}\text { Durable cell engraftment } \\
\text { Donor-specific HLA } \\
\text { alloantibodies development } \\
\text { Evidence of local donor-derived } \\
\text { myelination } \\
\text { No conclusive evidence of } \\
\text { superior myelination }\end{array}$ & $\begin{array}{l}\text { Gupta et al., } \\
2012,2019\end{array}$ \\
\hline CALD & $\begin{array}{l}\text { NCT00176904 } \\
\text { NCT00668564 } \\
\text { NCT00383448 }\end{array}$ & $\begin{array}{l}\text { II,III/Open label } \\
\text { II/Open label } \\
\text { II/Open label }\end{array}$ & Allogeneic HC & $\begin{array}{c}135 \\
18 \\
38\end{array}$ & $2.5-22.3$ y & IV & $\begin{array}{l}\text { Improved survival } \\
\text { Improved functional } \\
\text { Disability-free survival in early } \\
\text { stage patients with limited } \\
\text { cerebral disease at the time of } \\
\text { transplantation }\end{array}$ & $\begin{array}{l}\text { Peters et al., } \\
\text { 2004; Miller } \\
\text { et al., 2011; } \\
\text { Pierpont et al., } \\
\text { 2017; } \\
\text { Raymond et al., } \\
2019\end{array}$ \\
\hline EIKD & NA & Blinded & UCB & 19 & $\begin{array}{c}12-44 d \\
\text { or } \\
142-352 d\end{array}$ & IV & $\begin{array}{l}\text { Improved lifespan and } \\
\text { neurologic outcome in } \\
\text { asymptomatic neonates } \\
\text { No substantive neurologic } \\
\text { improvement after } \\
\text { symptoms have developed }\end{array}$ & $\begin{array}{l}\text { Escolar et al., } \\
\text { 2005; Wright } \\
\text { et al., 2017; } \\
\text { Allewelt et al., } \\
2018\end{array}$ \\
\hline
\end{tabular}

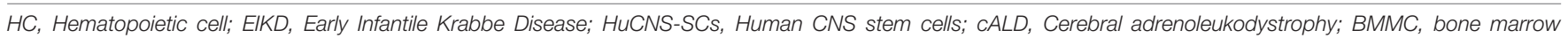
mononuclear cells; FLWM, frontal lobe white matter; y, Year; m, Month; d, Day.

1 (S1P1). Administration of FTY720 in neonatal model of oxygen-toxicity is reported to attenuate hyperoxia-induced hypomyelination through reduction of hyperoxia-induced oxidative stress and inflammation accompanied with direct protection of developing OLs (Serdar et al., 2016).

Several other drugs and biological compounds, such as Pioglitazone (PPAR- $\gamma$ agonist) (Yeh et al., 2021), Clemastine (M1 muscarinic acetylcholine receptor antagonist) (Cree et al., 2018), miconazole (ERK 1/2 activator) (Su et al., 2018), clobetasol (Smoothened receptor agonist) (Su et al., 2020) and IDR1018 (synthetic immunomodulator) (Bolouri et al., 2014) have been identified by HTS to have myelin enhancing property in preclinical and/or clinical trials, although their potential in treating prenatal WMI has not been explored.

\subsubsection{Environmental Enrichment and Nutritional Supplementation}

The third trimester of pregnancy, during which extreme premature infants are born, is a critical period of neurodevelopment and white matter maturation. The absence of placental nutrients along with low endogenous capacity to synthesize essential biomolecules, particularly in those born extremely preterm, may lead to neurodevelopmental impairment. Indeed, it has been shown that preterm infants have different nutritional needs than term infants (Keunen et al., 2015; Austin et al., 2019). Optimizing early nutritional support for preterm infants has the potential to improve neurodevelopmental outcomes. In this regard, short- and longchain polyunsaturated fatty acids (PUFAs) as well as cholesterol are indispensable building blocks for myelin production (Dimas et al., 2019; Hussain et al., 2019). Disturbance of cholesterol homeostasis following $\mathrm{HI}$ in neonatal brain was associated with worse subcortical white matter development (Kamino et al., 2019; Marangon et al., 2020). To this end, an ongoing clinical trial is currently evaluating the effect of early nutritional supply in brain maturation and neonatal outcomes in preterm infants (ClinicalTrials.gov NCT03555019) (Chan et al., 2016; Wendel et al., 2021). 
TABLE 3 | Pathways and compounds that have been investigated to enhance endogenous myelination and white matter development in perinatal WMI.

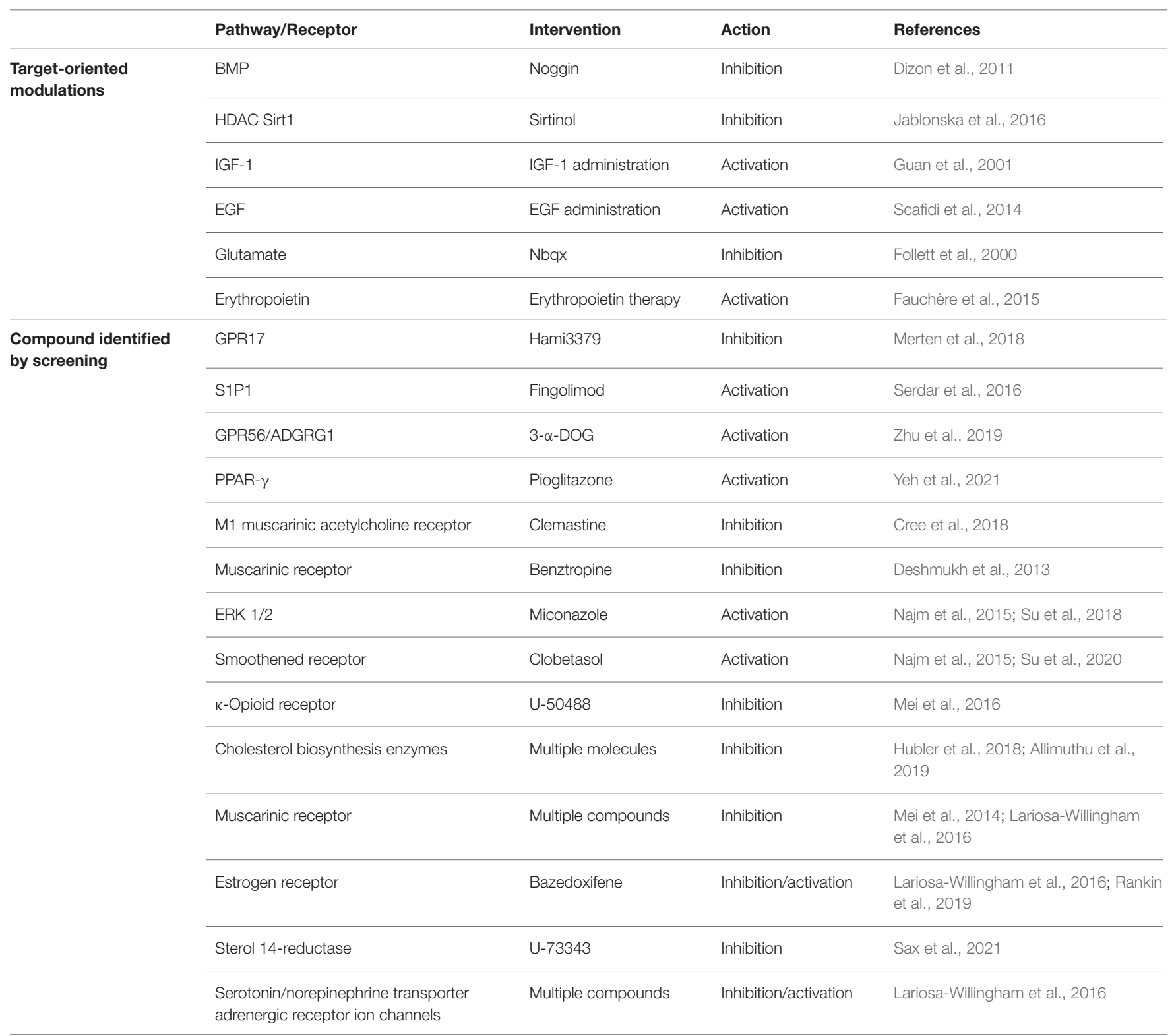

In addition to optimal early nutrition, the impacts of behavioral interventions and environmental enrichment (EE) have been increasingly appreciated in neurodevelopmental outcomes (Bacmeister et al., 2020; Tooley et al., 2021). Given that the peak of myelination occurs postnatally and continues into early adulthood, environmental enrichment (EE) has attracted major attention as a potential therapeutic strategy in improving neurodevelopmental outcomes (Bacmeister et al., 2020; Tooley et al., 2021). In supporting this notion, preclinical studies showed a reciprocal relationship between motor skill learning and oligodendrogenesis in the motor cortex (McKenzie et al., 2014; Bacmeister et al., 2020). While active myelination is essential for motor skill acquisition, motor learning increases oligodendrogenesis. Encouragingly, it has been demonstrated that early and continuous EE intervention- physical activity, increased socialization, and novel object exposure-attenuated perinatal HI-induced WMI via promotion of oligodendrogenesis and myelination, resulting in functional and behavioral recovery (Forbes et al., 2020). These results support the rationale for using motor skill training to improve myelination.

\section{CONCLUDING REMARKS}

Significant progress has been made in our understanding of OL development and myelination. However, more work needs to be done in both pathogenesis and treatment of WMI. Our knowledge on the leading pathophysiology of perinatal WMI remains two-decade old, which is pmOL maturation arrest (Back et al., 2002; Buser et al., 2012; Back, 2017). Single cell RNA 
sequencing (scRNA-seq) enables molecular characterization of each stages of OL development (Marques et al., 2016). Reexamining pmOLs in normal and WMI brains by scRNAseq may reveal new insights in the development of WMI at molecular level. For example, one important function of pmOLs is to ensheathe axons through F-actin polymerization. Is it possible that $\mathrm{HI}$ and neuroinflammation impair this essential developmental process thus leading to pmOL maturation arrest? As for the treatment, there is no effective therapy for WMI despite extensive preclinical efforts. Given the vulnerability of preterm

\section{REFERENCES}

Allewelt, H., Taskindoust, M., Troy, J., Page, K., Wood, S., Parikh, S., et al. (2018). Long-Term functional outcomes after hematopoietic stem cell transplant for early infantile krabbe disease. Biol. Blood Marrow Transplant. 24, 2233-2238. doi: 10.1016/j.bbmt.2018.06.020

Allimuthu, D., Hubler, Z., Najm, F. J., Tang, H., Bederman, I., Seibel, W., et al. (2019). Diverse chemical scaffolds enhance oligodendrocyte formation by inhibiting CYP51, TM7SF2, or EBP. Cell. Chem. Biol. 26, 593.e-599.e. doi: 10.1016/j.chembiol.2019.01.004

Almeida, R. G., Williamson, J. M., Madden, M. E., Early, J. J., Voas, M. G., Talbot, W. S., et al. (2021). Myelination induces axonal hotspots of synaptic vesicle fusion that promote sheath growth. Curr. Biol. 31, 3743-3754.e5. doi: 10.1016/ j.cub.2021.06.036

Amariglio, N., Hirshberg, A., Scheithauer, B. W., Cohen, Y., Loewenthal, R., Trakhtenbrot, L., et al. (2009). Donor-derived brain tumor following neural stem cell transplantation in an ataxia telangiectasia patient. PLoS Med 6:e1000029. doi: 10.1371/journal.pmed.1000029

Austin, S., De Castro, C. A., Sprenger, N., Binia, A., Affolter, M., GarciaRodenas, C. L., et al. (2019). Human milk oligosaccharides in the milk of mothers delivering term versus preterm infants. Nutrients 11:1282. doi: 10 . 3390/nu11061282

Back, S. A. (2017). White matter injury in the preterm infant: pathology and mechanisms. Acta Neuropathol. 134, 331-349. doi: 10.1007/s00401-017-1718-6

Back, S. A., and Volpe, J. J. (1997). Cellular and molecular pathogenesis of periventricular white matter injury. Ment. Retard. Dev. Disabil. Res. Rev. 3, 96-107. doi: 10.1002/(SICI)1098-277919973:1<96::AID-MRDD12<3.0.CO;2$\mathrm{M}$

Back, S. A., Gan, X., Li, Y., Rosenberg, P. A., and Volpe, J. J. (1998). Maturationdependent vulnerability of oligodendrocytes to oxidative stress-induced death caused by glutathione depletion. J. Neurosci. 18, 6241-6253. doi: 10.1523/ jneurosci.18-16-06241.1998

Back, S. A., Han, B. H., Luo, N. L., Chricton, C. A., Xanthoudakis, S., Tam, J., et al. (2002). Selective vulnerability of late oligodendrocyte progenitors to hypoxiaischemia. J. Neurosci. 22, 455-463. doi: 10.1523/jneurosci.22-02-00455.2002

Back, S. A., Luo, N. L., Mallinson, R. A., O'malley, J. P., Wallen, L. D., Frei, B., et al. (2005). Selective vulnerability of preterm white matter to oxidative damage defined by F2-isoprostanes. Ann. Neurol. 58, 108-120. doi: 10.1002/ana.20530

Bacmeister, C. M., Barr, H. J., Mcclain, C. R., Thornton, M. A., Nettles, D., Welle, C. G., et al. (2020). Motor learning promotes remyelination via new and surviving oligodendrocytes. Nat. Neurosci. 23, 819-831. doi: 10.1038/s41593020-0637-3

Baydyuk, M., Morrison, V. E., Gross, P. S., and Huang, J. K. (2020). Extrinsic factors driving oligodendrocyte lineage cell progression in CNS development and injury. Neurochem. Res. 45, 630-642. doi: 10.1007/s11064-020-02967-7

Bechler, M. E., Byrne, L., and Ffrench-Constant, C. (2015). CNS myelin sheath lengths are an intrinsic property of oligodendrocytes. Curr. Biol. 25, 2411-2416. doi: 10.1016/j.cub.2015.07.056

Berry, K., Wang, J., and Lu, Q. R. (2020). Epigenetic regulation of oligodendrocyte myelination in developmental disorders and neurodegenerative diseases. F1000Research 9:F1000FacultyRev-1105. doi: 10.12688/f1000research.20904.1

Billiards, S. S., Haynes, R. L., Folkerth, R. D., Borenstein, N. S., Trachtenberg, F. L., Rowitch, D. H., et al. (2008). Myelin abnormalities without oligodendrocyte loss infants and their full life expectancy, any therapeutic modality has to be safe with minimal short- and long-term adverse effect. To fulfill such criteria, UCBC transplantation, EE, and natural compounds derived from breast milk may hold promise in translating to human therapy.

\section{AUTHOR CONTRIBUTIONS}

MM and XP wrote and revised the manuscript. Both authors contributed to the article and approved the submitted version.

in periventricular leukomalacia. Brain Pathol. 18, 153-163. doi: 10.1111/j.17503639.2007.00107.x

Bolouri, H., Sävman, K., Wang, W., Thomas, A., Maurer, N., Dullaghan, E., et al. (2014). Innate defense regulator peptide 1018 protects against perinatal brain injury. Ann. Neurol. 75, 395-410. doi: 10.1002/ana.24087

Borhani-Haghighi, M., Mohamadi, Y., and Kashani, I. R. (2019). In utero transplantation of neural stem cells ameliorates maternal inflammationinduced prenatal white matter injury. J. Cell. Biochem. 120, 12785-12795. doi: 10.1002/jcb. 28548

Buser, J. R., Maire, J., Riddle, A., Gong, X., Nguyen, T., Nelson, K., et al. (2012). Arrested preoligodendrocyte maturation contributes to myelination failure in premature infants. Ann. Neurol. 71, 93-109. doi: 10.1002/ana.22627

Cai, Z., Fan, L. W., Lin, S., Pang, Y., and Rhodes, P. G. (2011). Intranasal administration of insulin-like growth factor-1 protects against lipopolysaccharide-induced injury in the developing rat brain. Neuroscience 194, 195-207. doi: 10.1016/j.neuroscience.2011.08.003

Cao, Y., Gunn, A. J., Bennet, L., Wu, D., George, S., Gluckman, P. D., et al. (2003). Insulin-like growth factor (IGF)-1 suppresses oligodendrocyte caspase3 activation and increases glial proliferation after ischemia in near-term fetal sheep. J. Cereb. Blood Flow Metab. 23, 739-747. doi: 10.1097/01.wcb. $0000067720.12805 .6 \mathrm{f}$

Cayre, M., Falque, M., Mercier, O., Magalon, K., and Durbec, P. (2021). Myelin repair: from animal models to humans. Front. Cell. Neurosci. 15:604865. doi: $10.3389 /$ fncel.2021.604865

Chan, S. H. T., Johnson, M. J., Leaf, A. A., and Vollmer, B. (2016). Nutrition and neurodevelopmental outcomes in preterm infants: a systematic review. Acta Paediatr. 105, 587-599. doi: 10.1111/apa.13344

Chapman, H., Waclaw, R. R., Pei, Z., Nakafuku, M., and Campbell, K. (2013). The homeobox gene Gsx2 controls the timing of oligodendroglial fate specification in mouse lateral ganglionic eminence progenitors. Development 140, 22892298. doi: 10.1242/dev.091090

Chen, L. X., Ma, S. M., Zhang, P., Fan, Z. C., Xiong, M., Cheng, G. Q., et al. (2015). Neuroprotective effects of oligodendrocyte progenitor cell transplantation in premature rat brain following hypoxic-ischemic injury. PLoS One 10:e0115997. doi: 10.1371/journal.pone.0115997

Chen, Y., Wang, H., Yoon, S. O., Xu, X., Hottiger, M. O., Svaren, J., et al. (2011). HDAC-mediated deacetylation of NF- $\kappa$ B is critical for Schwann cell myelination. Nat. Neurosci. 14, 437-441. doi: 10.1038/nn.2780

Cotten, C. M., Murtha, A. P., Goldberg, R. N., Grotegut, C. A., Smith, P. B., Goldstein, R. F., et al. (2014). Feasibility of autologous cord blood cells for infants with hypoxic-ischemic encephalopathy. J. Pediatr. 164, 973.e-979.e. doi: 10.1016/j.jpeds.2013.11.036

Craig, A., Luo, N. L., Beardsley, D. J., Wingate-Pearse, N., Walker, D. W., Hohimer, A. R., et al. (2003). Quantitative analysis of perinatal rodent oligodendrocyte lineage progression and its correlation with human. Exp. Neurol. 181, 231-240.

Cree, B.a.C, Niu, J., Hoi, K. K., Zhao, C., Caganap, S. D., Henry, R. G., et al. (2018). Clemastine rescues myelination defects and promotes functional recovery in hypoxic brain injury. Brain 141, 85-98. doi: 10.1093/brain/awx312

Cui, Q. L., and Almazan, G. (2007). IGF-I-induced oligodendrocyte progenitor proliferation requires PI3K/Akt, MEK/ERK, and Src-like tyrosine kinases. J. Neurochem. 100, 1480-1493. doi: 10.1111/j.1471-4159.2006.04329.x

Dawson, M. R., Polito, A., Levine, J. M., and Reynolds, R. (2003). NG2-expressing glial progenitor cells: an abundant and widespread population of cycling cells 
in the adult rat CNS. Mol. Cell. Neurosci. 24, 476-488. doi: 10.1016/s10447431(03)00210-0

Deshmukh, V. A., Tardif, V., Lyssiotis, C. A., Green, C. C., Kerman, B., Kim, H. J., et al. (2013). A regenerative approach to the treatment of multiple sclerosis. Nature 502, 327-332. doi: 10.1038/nature12647

Dimas, P., Montani, L., Pereira, J. A., Moreno, D., Trötzmüller, M., Gerber, J., et al. (2019). CNS myelination and remyelination depend on fatty acid synthesis by oligodendrocytes. Elife 8:e44702. doi: 10.7554/eLife.44702

Dizon, M. L. V., Maa, T., and Kessler, J. A. (2011). The bone morphogenetic protein antagonist noggin protects white matter after perinatal hypoxia-ischemia. Neurobiol. Dis. 42, 318-326. doi: 10.1016/j.nbd.2011.01.023

Elbaz, B., Aaker, J. D., Isaac, S., Kolarzyk, A., Brugarolas, P., Eden, A., et al. (2018). Phosphorylation state of ZFP24 controls oligodendrocyte differentiation. Cell Rep. 23, 2254-2263. doi: 10.1016/j.celrep.2018.04.089

Elbaz, B., and Popko, B. (2019). Molecular control of oligodendrocyte development. Trends Neurosci. 42, 263-277. doi: 10.1016/j.tins.2019.01.002

Eleuteri, C., Olla, S., Veroni, C., Umeton, R., Mechelli, R., Romano, S., et al. (2017). A staged screening of registered drugs highlights remyelinating drug candidates for clinical trials. Sci. Rep. 7:45780. doi: 10.1038/srep45780

Emery, B. (2010). Regulation of oligodendrocyte differentiation and myelination. Science 330, 779-782. doi: 10.1126/science.1190927

Escolar, M. L., Poe, M. D., Provenzale, J. M., Richards, K. C., Allison, J., Wood, S., et al. (2005). Transplantation of umbilical-cord blood in babies with infantile Krabbe's disease. N. Engl. J. Med. 352, 2069-2081. doi: 10.1056/NEJMoa042604

Fan, X., Heijnen, C. J., Van Der, K. M., Groenendaal, F., and Van Bel, F. (2011). Beneficial effect of erythropoietin on sensorimotor function and white matter after hypoxia-ischemia in neonatal mice. Pediatr. Res. 69, 56-61. doi: 10.1203/ PDR.0b013e3181fcbef3

Fauchère, J. C., Koller, B. M., Tschopp, A., Dame, C., Ruegger, C., and Bucher, H. U. (2015). Safety of early high-dose recombinant erythropoietin for neuroprotection in very preterm infants. J. Pediatr. 167, .e51-.e53. doi: 10.1016/ j.jpeds.2015.02.052

Folkerth, R. D., Haynes, R. L., Borenstein, N. S., Belliveau, R. A., Trachtenberg, F., Rosenberg, P. A., et al. (2004). Developmental lag in superoxide dismutases relative to other antioxidant enzymes in premyelinated human telencephalic white matter. J. Neuropathol. Exp. Neurol. 63, 990-999. doi: 10.1093/jnen/63.9. 990

Follett, P. L., Rosenberg, P. A., Volpe, J. J., and Jensen, F. E. (2000). NBQX attenuates excitotoxic injury in developing white matter. J. Neurosci. 20, 92359241. doi: 10.1523/JNEUROSCI.20-24-09235.2000

Folts, C. J., Giera, S., Li, T., and Piao, X. (2019). Adhesion G protein-coupled receptors as drug targets for neurological diseases. Trends Pharmacol. Sci. 40, 278-293. doi: 10.1016/j.tips.2019.02.003

Forbes, T. A., Goldstein, E. Z., Dupree, J. L., Jablonska, B., Scafidi, J., Adams, K. L., et al. (2020). Environmental enrichment ameliorates perinatal brain injury and promotes functional white matter recovery. Nat. Commun. 11:964. doi: 10.1038/s41467-020-14762-7

Franklin, R. J., and Ffrench-Constant, C. (2008). Remyelination in the CNS: from biology to therapy. Nat. Rev. Neurosci. 9, 839-855. doi: 10.1038/nrn2480

Gibson, E. M., Purger, D., Mount, C. W., Goldstein, A. K., Lin, G. L., Wood, L. S., et al. (2014). Neuronal activity promotes oligodendrogenesis and adaptive myelination in the mammalian brain. Science (New York, N.Y.) 344:1252304. doi: $10.1126 /$ science. 1252304

Goldman, S. A. (2016). Stem and progenitor cell-based therapy of the central nervous system: hopes, hype, and wishful thinking. Cell Stem Cell 18, 174-188. doi: $10.1016 /$ j.stem.2016.01.012

Goldman, S. A. (2017). Progenitor cell-based treatment of glial disease. Prog. Brain Res. 231, 165-189. doi: 10.1016/bs.pbr.2017.02.010

Goldman, S. A., Mariani, J. N., and Madsen, P. M. (2021). Glial progenitor cellbased repair of the dysmyelinated brain: progression to the clinic. Semin. Cell Dev. Biol. 116, 62-70. doi: 10.1016/j.semcdb.2020.12.004

Gregath, A., and Lu, Q. R. (2018). Epigenetic modifications-insight into oligodendrocyte lineage progression, regeneration, and disease. FEBS Lett. 592, 1063-1078. doi: 10.1002/1873-3468.12999

Guan, J., Bennet, L., George, S., Wu, D., Waldvogel, H. J., Gluckman, P. D., et al. (2001). Insulin-like growth factor-1 reduces postischemic white matter injury in fetal sheep. J. Cereb. Blood Flow Metab. 21, 493-502. doi: 10.1097/00004647200105000-00003
Gupta, N., Henry, R. G., Kang, S.-M., Strober, J., Lim, D. A., Ryan, T., et al. (2019). Long-Term safety, immunologic response, and imaging outcomes following neural stem cell transplantation for pelizaeus-merzbacher disease. Stem Cell Rep. 13, 254-261. doi: 10.1016/j.stemcr.2019.07.002

Gupta, N., Henry, R. G., Strober, J., Kang, S. M., Lim, D. A., Bucci, M., et al. (2012). Neural stem cell engraftment and myelination in the human brain. Sci. Transl. Med. 4:155ra137. doi: 10.1126/scitranslmed.3004373

Hamrick, S. E., Miller, S. P., Leonard, C., Glidden, D. V., Goldstein, R., Ramaswamy, V., et al. (2004). Trends in severe brain injury and neurodevelopmental outcome in premature newborn infants: the role of cystic periventricular leukomalacia. J. Pediatr. 145, 593-599. doi: 10.1016/j.jpeds. 2004. 05.042

Hansen-Pupp, I., Hövel, H., Hellström, A., Hellström-Westas, L., Löfqvist, C., Larsson, E.-M., et al. (2011). Postnatal decrease in circulating insulin-like growth factor-I and low brain volumes in very preterm infants. J. Clin. Endocrinol. Metab. 96, 1129-1135.

Haynes, R. L., Folkerth, R. D., Keefe, R. J., Sung, I., Swzeda, L. I., Rosenberg, P. A., et al. (2003). Nitrosative and oxidative injury to premyelinating oligodendrocytes in periventricular leukomalacia. J. Neuropathol. Exp. Neurol. 62, 441-450. doi: 10.1093/jnen/62.5.441

He, D., Marie, C., Zhao, C., Kim, B., Wang, J., Deng, Y., et al. (2016). Chd7 cooperates with Sox10 and regulates the onset of CNS myelination and remyelination. Nat. Neurosci. 19, 678-689. doi: 10.1038/nn.4258

He, X., Zhang, L., Queme, L. F., Liu, X., Lu, A., Waclaw, R. R., et al. (2018). A histone deacetylase 3-dependent pathway delimits peripheral myelin growth and functional regeneration. Nat. Med. 24, 338-351. doi: 10.1038/nm. 4483

Henriques, D., Moreira, R., Schwamborn, J., Pereira De Almeida, L., and Mendonça, L. S. (2019). Successes and hurdles in stem cells application and production for brain transplantation. Front. Neurosci. 13:1194. doi: 10.3389/ fnins.2019.01194

Hines, J. H., Ravanelli, A. M., Schwindt, R., Scott, E. K., and Appel, B. (2015). Neuronal activity biases axon selection for myelination in vivo. Nat. Neurosci. 18, 683-689. doi: $10.1038 / \mathrm{nn} .3992$

Huang, W., Bhaduri, A., Velmeshev, D., Wang, S., Wang, L., Rottkamp, C. A., et al. (2020). Origins and proliferative states of human oligodendrocyte precursor cells. Cell 182, 594.e-608.e. doi: 10.1016/j.cell.2020.06.027

Hubler, Z., Allimuthu, D., Bederman, I., Elitt, M. S., Madhavan, M., Allan, K. C., et al. (2018). Accumulation of 8,9-unsaturated sterols drives oligodendrocyte formation and remyelination. Nature 560, 372-376. doi: 10.1038/s41586-018$0360-3$

Hughes, E. G., Kang, S. H., Fukaya, M., and Bergles, D. E. (2013). Oligodendrocyte progenitors balance growth with self-repulsion to achieve homeostasis in the adult brain. Nat. Neurosci. 16, 668-676. doi: 10.1038/nn.3390

Hussain, G., Wang, J., Rasul, A., Anwar, H., Imran, A., Qasim, M., et al. (2019). Role of cholesterol and sphingolipids in brain development and neurological diseases. Lipids Health Dis. 18:26. doi: 10.1186/s12944-019-0965-Z

Iwai, M., Stetler, R. A., Xing, J., Hu, X., Gao, Y., Zhang, W., et al. (2010). Enhanced oligodendrogenesis and recovery of neurological function by erythropoietin after neonatal hypoxic/ischemic brain injury. Stroke 41, 1032-1037. doi: 10. 1161/STROKEAHA.109.570325

Jablonska, B., Gierdalski, M., Chew, L.-J., Hawley, T., Catron, M., Lichauco, A., et al. (2016). Sirt1 regulates glial progenitor proliferation and regeneration in white matter after neonatal brain injury. Nat. Commun. 7:13866. doi: 10.1038/ ncomms 13866

Jakovcevski, I., Filipovic, R., Mo, Z., Rakic, S., and Zecevic, N. (2009). Oligodendrocyte development and the onset of myelination in the human fetal brain. Front. Neuroanat. 3:5. doi: 10.3389/neuro.05.005.2009

Jantzie, L. L., Miller, R. H., and Robinson, S. (2013). Erythropoietin signaling promotes oligodendrocyte development following prenatal systemic hypoxic-ischemic brain injury. Pediatr. Res. 74, 658-667. doi: 10.1038/pr.20 13.155

Jung, J. W., Kwon, M., Choi, J. C., Shin, J. W., Park, I. W., Choi, B. W., et al. (2013). Familial occurrence of pulmonary embolism after intravenous, adipose tissuederived stem cell therapy. Yonsei Med. J. 54, 1293-1296. doi: 10.3349/ymj.2013. 54.5.1293

Juul, S. E., Comstock, B. A., Wadhawan, R., Mayock, D. E., Courtney, S. E., Robinson, T., et al. (2020). A randomized trial of erythropoietin for 
neuroprotection in preterm infants. N. Engl. J. Med. 382, 233-243. doi: 10.1056/ NEJMoa1907423

Kako, E., Kaneko, N., Aoyama, M., Hida, H., Takebayashi, H., Ikenaka, K., et al. (2012). Subventricular zone-derived oligodendrogenesis in injured neonatal white matter in mice enhanced by a nonerythropoietic erythropoietin derivative. Stem Cells 30, 2234-2247. doi: 10.1002/ stem. 1202

Kamino, D., Chau, V., Studholme, C., Liu, M., Xu, D., Barkovich, A. J., et al. (2019). Plasma cholesterol levels and brain development in preterm newborns. Pediatr. Res. 85, 299-304. doi: 10.1038/s41390-018-0260-0

Kang, M., Min, K., Jang, J., Kim, S. C., Kang, M. S., Jang, S. J., et al. (2015). Involvement of immune responses in the efficacy of cord blood cell therapy for cerebral palsy. Stem Cells Dev. 24, 2259-2268. doi: 10.1089/scd.2015. 0074

Kessaris, N., Fogarty, M., Iannarelli, P., Grist, M., Wegner, M., and Richardson, W. D. (2006). Competing waves of oligodendrocytes in the forebrain and postnatal elimination of an embryonic lineage. Nat. Neurosci. 9, 173-179. doi: $10.1038 / \mathrm{nn} 1620$

Keunen, K., Van Elburg, R. M., Van Bel, F., and Benders, M. J. N. L. (2015). Impact of nutrition on brain development and its neuroprotective implications following preterm birth. Pediatr. Res. 77, 148-155. doi: 10.1038/pr.2014.171

Khwaja, O., and Volpe, J. J. (2008). Pathogenesis of cerebral white matter injury of prematurity. Arch. Dis.Child. Fetal Neonatal Ed. 93, F153-F161. doi: 10.1136/ adc.2006.108837

Kim, T.-K., Park, D., Ban, Y.-H., Cha, Y., An, E. S., Choi, J., et al. (2018). Improvement by human oligodendrocyte progenitor cells of neurobehavioral disorders in an experimental model of neonatal periventricular leukomalacia. Cell Transplant. 27, 1168-1177. doi: 10.1177/09636897187 81330

Knabe, W., Knerlich, F., Washausen, S., Kietzmann, T., Sirén, A. L., Brunnett, G., et al. (2004). Expression patterns of erythropoietin and its receptor in the developing midbrain. Anat. Embryol. (Berl) 207, 503-512. doi: 10.1007/s00429003-0365-y

Koudelka, S., Voas, M. G., Almeida, R. G., Baraban, M., Soetaert, J., Meyer, M. P., et al. (2016). Individual neuronal subtypes exhibit diversity in CNS myelination mediated by synaptic vesicle release. Curr. Biol. 26, 1447-1455. doi: 10.1016/j. cub.2016.03.070

Kurachi, M., Mikuni, M., and Ishizaki, Y. (2016). Extracellular vesicles from vascular endothelial cells promote survival, proliferation and motility of oligodendrocyte precursor cells. PLoS One 11:e0159158. doi: 10.1371/journal. pone. 0159158

Lariosa-Willingham, K. D., Rosler, E. S., Tung, J. S., Dugas, J. C., Collins, T. L., and Leonoudakis, D. (2016). A high throughput drug screening assay to identify compounds that promote oligodendrocyte differentiation using acutely dissociated and purified oligodendrocyte precursor cells. BMC Res. Notes 9:419. doi: 10.1186/s13104-016-2220-2

Lee, S., Chong, S. Y., Tuck, S. J., Corey, J. M., and Chan, J. R. (2013). A rapid and reproducible assay for modeling myelination by oligodendrocytes using engineered nanofibers. Nat. Protoc. 8, 771-782. doi: 10.1038/nprot.2013.039

Leuchter, R. H., Gui, L., Poncet, A., Hagmann, C., Lodygensky, G. A., Martin, E., et al. (2014). Association between early administration of high-dose erythropoietin in preterm infants and brain MRI abnormality at term-equivalent age. JAMA 312, 817-824. doi: 10.1001/jama.20 14.9645

Ley, D., Hansen-Pupp, I., Niklasson, A., Domellöf, M., Friberg, L. E., Borg, J., et al. (2013). Longitudinal infusion of a complex of insulin-like growth factorI and IGF-binding protein-3 in five preterm infants: pharmacokinetics and short-term safety. Pediatr. Res. 73, 68-74. doi: 10.1038/pr.20 12.146

Li, J., Yawno, T., Sutherland, A. E., Gurung, S., Paton, M., Mcdonald, C., et al. (2018). Preterm umbilical cord blood derived mesenchymal stem/stromal cells protect preterm white matter brain development against hypoxia-ischemia. Exp. Neurol. 308, 120-131. doi: 10.1016/j.expneurol.2018.07.006

Li, J., Yawno, T., Sutherland, A., Loose, J., Nitsos, I., Bischof, R., et al. (2016). Preterm white matter brain injury is prevented by early administration of umbilical cord blood cells. Exp. Neurol. 283, 179-187. doi: 10.1016/j.expneurol. 2016.06.017
Ligon, K. L., Kesari, S., Kitada, M., Sun, T., Arnett, H. A., Alberta, J. A., et al. (2006). Development of NG2 neural progenitor cells requires Olig gene function. Proc. Natl. Acad. Sci. U.S.A. 103, 7853-7858. doi: 10.1073/pnas.05110 01103

Lin, S., Fan, L.-W., Rhodes, P. G., and Cai, Z. (2009). Intranasal administration of IGF-1 attenuates hypoxic-ischemic brain injury in neonatal rats. Exp. Neurol. 217, 361-370. doi: 10.1016/j.expneurol.2009.03.021

Liu, W., Shen, Y., Plane, J. M., Pleasure, D. E., and Deng, W. (2011). Neuroprotective potential of erythropoietin and its derivative carbamylated erythropoietin in periventricular leukomalacia. Exp. Neurol. 230, 227-239. doi: 10.1016/j.expneurol.2011.04.021

Liu, X. B., Shen, Y., Plane, J. M., and Deng, W. (2013). Vulnerability of premyelinating oligodendrocytes to white-matter damage in neonatal brain injury. Neurosci. Bull. 29, 229-238. doi: 10.1007/s12264-013-1311-5

Lu, Q. R., Sun, T., Zhu, Z., Ma, N., Garcia, M., Stiles, C. D., et al. (2002). Common developmental requirement for Olig function indicates a motor neuron/oligodendrocyte connection. Cell 109, 75-86. doi: 10.1016/s00928674(02)00678-5

Lyssiotis, C. A., Walker, J., Wu, C., Kondo, T., Schultz, P. G., and Wu, X. (2007). Inhibition of histone deacetylase activity induces developmental plasticity in oligodendrocyte precursor cells. Proc. Natl. Acad. Sci. U.S.A. 104, 14982-14987. doi: 10.1073/pnas.0707044104

Mangin, J.-M., Li, P., Scafidi, J., and Gallo, V. (2012). Experience-dependent regulation of NG2 progenitors in the developing barrel cortex. Nat. Neurosci. 15, 1192-1194. doi: 10.1038/nn.3190

Manousi, A., Göttle, P., Reiche, L., Cui, Q.-L., Healy, L. M., Akkermann, R., et al. (2021). Identification of novel myelin repair drugs by modulation of oligodendroglial differentiation competence. EBioMedicine 65:103276. doi: 10. 1016/j.ebiom.2021.103276

Marangon, D., Boccazzi, M., Lecca, D., and Fumagalli, M. (2020). Regulation of oligodendrocyte functions: targeting lipid metabolism and extracellular matrix for myelin repair. J. Clin. Med. 9:470. doi: 10.3390/jcm9020470

Marin-Husstege, M., Muggironi, M., Liu, A., and Casaccia-Bonnefil, P. (2002). Histone deacetylase activity is necessary for oligodendrocyte lineage progression. J. Neurosci. 22, 10333-10345. doi: 10.1523/jneurosci.22-23-10333. 2002

Marques, S., Zeisel, A., Codeluppi, S., Van Bruggen, D., Mendanha Falcão, A., Xiao, L., et al. (2016). Oligodendrocyte heterogeneity in the mouse juvenile and adult central nervous system. Science 352, 1326-1329. doi: 10.1126/science. aaf6463

Mason, J. L., Xuan, S., Dragatsis, I., Efstratiadis, A., and Goldman, J. E. (2003). Insulin-like growth factor (IGF) signaling through type 1 IGF receptor plays an important role in remyelination. J. Neurosci. 23, 7710-7718. doi: 10.1523/ jneurosci.23-20-07710.2003

Matejuk, A., and Ransohoff, R. M. (2020). Crosstalk between astrocytes and microglia: an overview. Front. Immunol. 11:1416. doi: 10.3389/fimmu.2020. 01416

Mazur, M., Miller, R. H., and Robinson, S. (2010). Postnatal erythropoietin treatment mitigates neural cell loss after systemic prenatal hypoxic-ischemic injury. J. Neurosurg. Pediatr. 6, 206-221. doi: 10.3171/2010.5.peds1032

McKenzie, I. A., Ohayon, D., Li, H., De Faria, J. P., Emery, B., Tohyama, K., et al. (2014). Motor skill learning requires active central myelination. Science 346, 318-322. doi: 10.1126/science. 1254960

Mei, F., Fancy, S. P. J., Shen, Y.-a.A, Niu, J., Zhao, C., Presley, B., et al. (2014). Micropillar arrays as a high-throughput screening platform for therapeutics in multiple sclerosis. Nat. Med. 20, 954-960. doi: 10.1038/nm.3618

Mei, F., Mayoral, S. R., Nobuta, H., Wang, F., Desponts, C., Lorrain, D. S., et al. (2016). Identification of the kappa-opioid receptor as a therapeutic target for oligodendrocyte remyelination. J. Neurosci. 36, 7925-7935. doi: 10.1523/ jneurosci.1493-16.2016

Merten, N., Fischer, J., Simon, K., Zhang, L., Schröder, R., Peters, L., et al. (2018). Repurposing HAMI3379 to block GPR17 and promote rodent and human oligodendrocyte differentiation. Cell. Chem. Biol. 25, 775.e-786.e. doi: 10.1016/ j.chembiol.2018.03.012

Miller, W. P., Rothman, S. M., Nascene, D., Kivisto, T., Defor, T. E., Ziegler, R. S., et al. (2011). Outcomes after allogeneic hematopoietic cell transplantation for childhood cerebral adrenoleukodystrophy: the largest single-institution 
cohort report. Blood 118, 1971-1978. doi: 10.1182/blood-2011-01329235

Min, K., Song, J., Kang, J. Y., Ko, J., Ryu, J. S., Kang, M. S., et al. (2013). Umbilical cord blood therapy potentiated with erythropoietin for children with cerebral palsy: a double-blind, randomized, placebo-controlled trial. Stem Cells 31, 581-591. doi: 10.1002/stem.1304

Mitew, S., Gobius, I., Fenlon, L. R., Mcdougall, S. J., Hawkes, D., Xing, Y. L., et al. (2018). Pharmacogenetic stimulation of neuronal activity increases myelination in an axon-specific manner. Nat. Commun. 9:306. doi: 10.1038/s41467-01702719-2

Mogha, A., D'rozario, M., and Monk, K. R. (2016). G protein-coupled receptors in myelinating glia. Trends Pharmacol. Sci. 37, 977-987. doi: 10.1016/j.tips.2016. 09.002

Najm, F. J., Madhavan, M., Zaremba, A., Shick, E., Karl, R. T., Factor, D. C., et al. (2015). Drug-based modulation of endogenous stem cells promotes functional remyelination in vivo. Nature 522, 216-220. doi: 10.1038/nature 14335

Nawaz, S., Sánchez, P., Schmitt, S., Snaidero, N., Mitkovski, M., Velte, C., et al. (2015). Actin filament turnover drives leading edge growth during myelin sheath formation in the central nervous system. Dev. Cell 34, 139-151. doi: 10.1016/j.devcel.2015.05.013

Nguyen, L. T., Nguyen, A. T., Vu, C. D., Ngo, D. V., and Bui, A. V. (2017). Outcomes of autologous bone marrow mononuclear cells for cerebral palsy: an open label uncontrolled clinical trial. BMC Pediatr. 17:104. doi: 10.1186/s12887017-0859-z

Nobuta, H., Ghiani, C. A., Paez, P. M., Spreuer, V., Dong, H., Korsak, R. A., et al. (2012). STAT3-mediated astrogliosis protects myelin development in neonatal brain injury. Ann. Neurol. 72, 750-765. doi: 10.1002/ana.23670

Ogawa, S., Hagiwara, M., Misumi, S., Tajiri, N., Shimizu, T., Ishida, A., et al. (2020). Transplanted oligodendrocyte progenitor cells survive in the brain of a rat neonatal white matter injury model but less mature in comparison with the normal brain. Cell Transplant. 29:0963689720946092. doi: 10.1177/ 0963689720946092

O’Gorman, R. L., Bucher, H. U., Held, U., Koller, B. M., Hüppi, P. S., and Hagmann, C. F. (2015). Tract-based spatial statistics to assess the neuroprotective effect of early erythropoietin on white matter development in preterm infants. Brain 138, 388-397. doi: 10.1093/brain/awu363

Orduz, D., Benamer, N., Ortolani, D., Coppola, E., Vigier, L., Pierani, A., et al. (2019). Developmental cell death regulates lineage-related interneuronoligodendroglia functional clusters and oligodendrocyte homeostasis. Nat. Commun. 10:4249. doi: 10.1038/s41467-019-11904-4

Paton, M. C. B., Allison, B. J., Li, J., Fahey, M. C., Sutherland, A. E., Nitsos, I., et al. (2018). Human umbilical cord blood therapy protects cerebral white matter from systemic LPS exposure in preterm fetal sheep. Dev. Neurosci. 40, 258-270. doi: $10.1159 / 000490943$

Pease-Raissi, S. E., and Chan, J. R. (2021). Building a (w)rapport between neurons and oligodendroglia: reciprocal interactions underlying adaptive myelination. Neuron 109, 1258-1273. doi: 10.1016/j.neuron.2021.02.003

Peters, C., Charnas, L. R., Tan, Y., Ziegler, R. S., Shapiro, E. G., Defor, T., et al. (2004). Cerebral X-linked adrenoleukodystrophy: the international hematopoietic cell transplantation experience from 1982 to 1999. Blood 104, 881-888. doi: 10.1182/blood-2003-10-3402

Pierpont, E. I., Eisengart, J. B., Shanley, R., Nascene, D., Raymond, G. V., Shapiro, E. G., et al. (2017). Neurocognitive trajectory of boys who received a hematopoietic stem cell transplant at an early stage of childhood cerebral adrenoleukodystrophy. JAMA Neurol. 74, 710-717. doi: 10.1001/jamaneurol. 2017.0013

Porambo, M., Phillips, A. W., Marx, J., Ternes, K., Arauz, E., Pletnikov, M., et al. (2015). Transplanted glial restricted precursor cells improve neurobehavioral and neuropathological outcomes in a mouse model of neonatal white matter injury despite limited cell survival. Glia 63, 452-465. doi: 10.1002/glia. 22764

Potter, G. B., Rowitch, D. H., and Petryniak, M. A. (2011). Myelin restoration: progress and prospects for human cell replacement therapies. Arch. Immunol. Ther. Exp. 59:179. doi: 10.1007/s00005-011-0120-7

Rankin, K. A., Mei, F., Kim, K., Shen, Y.-A.A, Mayoral, S. R., Desponts, C., et al. (2019). Selective estrogen receptor modulators enhance CNS remyelination independent of estrogen receptors. J. Neurosci. 39:2184. doi: 10.1523/JNEUROSCI.1530-18.2019

Rantakari, K., Rinta-Koski, O. P., Metsäranta, M., Hollmén, J., Särkkä, S., Rahkonen, P., et al. (2021). Early oxygen levels contribute to brain injury in extremely preterm infants. Pediatr. Res. 90, 131-139. doi: 10.1038/s41390-02101460-3

Rash, B. G., Duque, A., Morozov, Y. M., Arellano, J. I., Micali, N., and Rakic, P. (2019). Gliogenesis in the outer subventricular zone promotes enlargement and gyrification of the primate cerebrum. Proc. Natl. Acad. Sci. 116:7089. doi: 10.1073/pnas.1822169116

Raymond, G. V., Aubourg, P., Paker, A., Escolar, M., Fischer, A., Blanche, S., et al. (2019). Survival and functional outcomes in boys with cerebral adrenoleukodystrophy with and without hematopoietic stem cell transplantation. Biology of Blood Marrow Transplant. 25, 538-548. doi: 10.1016/j.bbmt.2018.09.036

Ren, Z., Xu, F., Zhang, X., Zhang, C., Miao, J., Xia, X., et al. (2020). Autologous cord blood cell infusion in preterm neonates safely reduces respiratory support duration and potentially preterm complications. Stem Cells Translat. Med. 9, 169-176. doi: 10.1002/sctm.19-0106

Riddle, A., Dean, J., Buser, J. R., Gong, X., Maire, J., Chen, K., et al. (2011). Histopathological correlates of magnetic resonance imaging-defined chronic perinatal white matter injury. Ann. Neurol. 70, 493-507. doi: 10.1002/ana. 22501

Rowitch, D. H., and Kriegstein, A. R. (2010). Developmental genetics of vertebrate glial-cell specification. Nature 468, 214-222. doi: 10.1038/nature09611

Ruff, C. A., Ye, H., Legasto, J. M., Stribbell, N. A., Wang, J., Zhang, L., et al. (2013). Effects of adult neural precursor-derived myelination on axonal function in the perinatal congenitally dysmyelinated brain: optimizing time of intervention, developing accurate prediction models, and enhancing performance. J. Neurosci. 33, 11899-11915. doi: 10.1523/jneurosci.1131-13. 2013

Rumajogee, P., Altamentova, S., Li, L., Li, J., Wang, J., Kuurstra, A., et al. (2018). Exogenous neural precursor cell transplantation results in structural and functional recovery in a hypoxic-ischemic hemiplegic mouse model. eNeuro 5:ENEURO.0369-18.2018. doi: 10.1523/eneuro.0369-18.2018

Ruscher, K., Freyer, D., Karsch, M., Isaev, N., Megow, D., Sawitzki, B., et al. (2002). Erythropoietin is a paracrine mediator of ischemic tolerance in the brain: evidence from an in vitro model. J. Neurosci. 22, 10291-10301. doi: 10.1523/jneurosci.22-23-10291.2002

Salmaso, N., Jablonska, B., Scafidi, J., Vaccarino, F. M., and Gallo, V. (2014). Neurobiology of premature brain injury. Nat. Neurosci. 17, 341-346. doi: 10. 1038/nn.3604

Salzman, G. S., Zhang, S., Fernandez, C. G., Araç, D., and Koide, S. (2020). Specific and direct modulation of the interaction between adhesion GPCR GPR56/ADGRG1 and tissue transglutaminase 2 using synthetic ligands. Sci. Rep. 10:16912. doi: 10.1038/s41598-020-74044-6

Sax, J. L., Hubler, Z., Allimuthu, D., and Adams, D. J. (2021). Screening reveals sterol derivatives with pro-differentiation, pro-survival, or potent cytotoxic effects on oligodendrocyte progenitor cells. ACS Chem. Biol. 16, 1288-1297. doi: 10.1021/acschembio.1c00461

Scafidi, J., Hammond, T. R., Scafidi, S., Ritter, J., Jablonska, B., Roncal, M., et al. (2014). Intranasal epidermal growth factor treatment rescues neonatal brain injury. Nature 506, 230-234. doi: 10.1038/nature12880

Segovia, K. N., Mcclure, M., Moravec, M., Luo, N. L., Wan, Y., Gong, X., et al. (2008). Arrested oligodendrocyte lineage maturation in chronic perinatal white matter injury. Ann. Neurol. 63, 520-530. doi: 10.1002/ana. 21359

Serdar, M., Herz, J., Kempe, K., Lumpe, K., Reinboth, B. S., Sizonenko, S. V., et al. (2016). Fingolimod protects against neonatal white matter damage and longterm cognitive deficits caused by hyperoxia. Brain Behav. Immun. 52, 106-119. doi: 10.1016/j.bbi.2015.10.004

Shingo, T., Sorokan, S. T., Shimazaki, T., and Weiss, S. (2001). Erythropoietin regulates the in vitro and in vivo production of neuronal progenitors by mammalian forebrain neural stem cells. J. Neurosci. 21, 9733-9743. doi: 10. 1523/jneurosci.21-24-09733.2001

Simpson, P. B., and Armstrong, R. C. (1999). Intracellular signals and cytoskeletal elements involved in oligodendrocyte progenitor migration. Glia 26, 22-35. 
Sobottka, B., Ziegler, U., Kaech, A., Becher, B., and Goebels, N. (2011). CNS live imaging reveals a new mechanism of myelination: the liquid croissant model. Glia 59, 1841-1849. doi: 10.1002/glia.21228

Sola, A., Wen, T.-C., Hamrick, S. E. G., and Ferriero, D. M. (2005). Potential for protection and repair following injury to the developing brain: a role for erythropoietin? Pediatr. Res. 57, 110-117. doi: 10.1203/01.PDR.0000159571. 50758.39

Sosunov, S. A., Niatsetskaya, Z. V., Stepanova, A. A., Galkin, A. S., Juliano, C. E., Ratner, V. I., et al. (2021). Developmental window of vulnerability to white matter injury driven by sublethal intermittent hypoxemia. Pediatr. Res. doi: 10.1038/s41390-021-01555-x [Epub ahead of print].

Spaas, J., Van Veggel, L., Schepers, M., Tiane, A., Van Horssen, J., Wilson, D. M., et al. (2021). Oxidative stress and impaired oligodendrocyte precursor cell differentiation in neurological disorders. Cell. Mol. Life Sci. 78, 4615-4637. doi: 10.1007/s00018-021-03802-0

Steelman, A. J., and Li, J. (2011). Poly(I:C) promotes TNF $\alpha /$ TNFR1-dependent oligodendrocyte death in mixed glial cultures. J Neuroinflammation 8:89. doi: 10.1186/1742-2094-8-89

Steiner, B., Roch, M., Holtkamp, N., and Kurtz, A. (2012). Systemically administered human bone marrow-derived mesenchymal stem home into peripheral organs but do not induce neuroprotective effects in the MCAomouse model for cerebral ischemia. Neurosci. Lett. 513, 25-30. doi: 10.1016/j. neulet.2012.01.078

Stoveken, H. M., Larsen, S. D., Smrcka, A. V., and Tall, G. G. (2018). Geduninand Khivorin-Derivatives are small-molecule partial agonists for adhesion g protein-coupled receptors GPR56/ADGRG1 and GPR114/ADGRG5. Mol. Pharmacol. 93, 477-488. doi: 10.1124/mol.117.111476

Su, X., Tang, W., Luan, Z., Yang, Y., Wang, Z., Zhang, Y., et al. (2018). Protective effect of miconazole on rat myelin sheaths following premature infant cerebral white matter injury. Exp. Ther. Med. 15, 2443-2449. doi: 10.3892/etm.2018. 5717

Su, X., Yuan, H., Bai, Y., Chen, J., Sui, M., Zhang, X., et al. (2020). Clobetasol attenuates white matter injury by promoting oligodendrocyte precursor cell differentiation. Pediatr. Neurosurg. 55, 188-196. doi: 10.1159/000509521

Suárez, R., Fenlon, Laura, R., Marek, R., Avitan, L., Sah, P., Goodhill, Geoffrey, J., et al. (2014). Balanced interhemispheric cortical activity is required for correct targeting of the corpus callosum. Neuron 82, 1289-1298. doi: 10.1016/j.neuron. 2014.04.040

Sun, J. M., Song, A. W., Case, L. E., Mikati, M. A., Gustafson, K. E., Simmons, R., et al. (2017). Effect of autologous cord blood infusion on motor function and brain connectivity in young children with cerebral palsy: a randomized, placebo-controlled trial. Stem Cells Transl. Med. 6, 2071-2078. doi: 10.1002/ sctm.17-0102

Thanh, L. N., Trung, K. N., Duy, C. V., Van, D. N., Hoang, P. N., Phuong, A. N. T., et al. (2019). Improvement in gross motor function and muscle tone in children with cerebral palsy related to neonatal icterus: an openlabel, uncontrolled clinical trial. BMC Pediatr. 19:290. doi: 10.1186/s12887-019$1669-2$

Tiane, A., Schepers, M., Rombaut, B., Hupperts, R., Prickaerts, J., Hellings, N., et al. (2019). From OPC to oligodendrocyte: an epigenetic journey. Cells 8:1236. doi: 10.3390/cells 8101236

Tooley, U. A., Bassett, D. S., and Mackey, A. P. (2021). Environmental influences on the pace of brain development. Nat. Rev. Neurosci. 22, 372-384. doi: 10.1038/ s41583-021-00457-5

Traiffort, E., Kassoussi, A., Zahaf, A., and Laouarem, Y. (2020). Astrocytes and microglia as major players of myelin production in normal and pathological conditions. Front. Cell. Neurosci. 14:79. doi: 10.3389/fncel.2020. 00079

Tsai, H. H., Niu, J., Munji, R., Davalos, D., Chang, J., Zhang, H., et al. (2016). Oligodendrocyte precursors migrate along vasculature in the developing nervous system. Science 351, 379-384. doi: 10.1126/science.aad3839

van Tilborg, E., Achterberg, E. J. M., Van Kammen, C. M., Van Der Toorn, A., Groenendaal, F., Dijkhuizen, R. M., et al. (2018a). Combined fetal inflammation and postnatal hypoxia causes myelin deficits and autism-like behavior in a rat model of diffuse white matter injury. Glia 66, 78-93. doi: 10.1002/glia. 23216 van Tilborg, E., De Theije, C. G. M., Van Hal, M., Wagenaar, N., De Vries, L. S., Benders, M. J., et al. (2018b). Origin and dynamics of oligodendrocytes in the developing brain: implications for perinatal white matter injury. Glia 66, 221-238. doi: 10.1002/glia.23256

Volpe, J. J. (2003). Cerebral white matter injury of the premature infant-more common than you think. Pediatrics 112, 176-180. doi: 10.1542/peds.112.1.176

Volpe, J. J. (2017). Confusions in nomenclature: "Periventricular Leukomalacia" and "White Matter Injury"-identical, distinct, or overlapping? Pediatr. Neurol. 73, 3-6. doi: 10.1016/j.pediatrneurol.2017.05.013

Volpe, J. J., Kinney, H. C., Jensen, F. E., and Rosenberg, P. A. (2011). The developing oligodendrocyte: key cellular target in brain injury in the premature infant. Int. J. Dev. Neurosci. 29, 423-440. doi: 10.1016/j.ijdevneu.2011.02.012

Wang, F., Ren, S.-Y., Chen, J.-F., Liu, K., Li, R.-X., Li, Z.-F., et al. (2020). Myelin degeneration and diminished myelin renewal contribute to age-related deficits in memory. Nat. Neurosci. 23, 481-486. doi: 10.1038/s41593-0200588-8

Wang, F., Yang, Y.-J., Yang, N., Chen, X.-J., Huang, N.-X., Zhang, J., et al. (2018). Enhancing oligodendrocyte myelination rescues synaptic loss and improves functional recovery after chronic hypoxia. Neuron 99, 689.e-701.e. doi: 10.1016/ j.neuron.2018.07.017

Wang, L., Zhang, Z., Wang, Y., Zhang, R., and Chopp, M. (2004). Treatment of stroke with erythropoietin enhances neurogenesis and angiogenesis and improves neurological function in rats. Stroke 35, 1732-1737. doi: 10.1161/01. STR.0000132196.49028.a4

Wang, S., Bates, J., Li, X., Schanz, S., Chandler-Militello, D., Levine, C., et al. (2013). Human iPSC-derived oligodendrocyte progenitor cells can myelinate and rescue a mouse model of congenital hypomyelination. Cell Stem Cell 12, 252-264. doi: 10.1016/j.stem.2012.12.002

Wang, X., Cheng, H., Hua, R., Yang, J., Dai, G., Zhang, Z., et al. (2013). Effects of bone marrow mesenchymal stromal cells on gross motor function measure scores of children with cerebral palsy: a preliminary clinical study. Cytotherapy 15, 1549-1562. doi: 10.1016/j.jcyt.2013.06.001

Wendel, K., Pfeiffer, H. C. V., Fugelseth, D. M., Nestaas, E., Domellöf, M., Skålhegg, B. S., et al. (2021). Effects of nutrition therapy on growth, inflammation and metabolism in immature infants: a study protocol of a double-blind randomized controlled trial (ImNuT). BMC Pediatr. 21:19. doi: 10.1186/s12887-02002425-x

Windrem, M. S., Schanz, S. J., Guo, M., Tian, G.-F., Washco, V., Stanwood, N., et al. (2008). Neonatal chimerization with human glial progenitor cells can both remyelinate and rescue the otherwise lethally hypomyelinated shiverer mouse. Cell Stem Cell 2, 553-565. doi: 10.1016/j.stem.2008. 03.020

Wright, M. D., Poe, M. D., Derenzo, A., Haldal, S., and Escolar, M. L. (2017). Developmental outcomes of cord blood transplantation for Krabbe disease: a 15-year study. Neurology 89, 1365-1372. doi: 10.1212/WNL. 0000000000004418

Wu, C. J., Wang, Z. Y., Yang, Y. X., and Luan, Z. (2017). [Long-term effect of oligodendrocyte precursor cell transplantation on a rat model of white matter injury in the preterm infant]. Zhongguo Dang Dai Er Ke Za Zhi 19, 1003-1007. doi: 10.7499/j.issn.1008-8830.2017.09.014

Wu, Z., Zhang, S., Zhou, L., Cai, J., Tan, J., Gao, X., et al. (2017). Thromboembolism induced by umbilical cord mesenchymal stem cell infusion: a report of two cases and literature review. Transplant. Proc. 49, 1656-1658. doi: 10.1016/j. transproceed.2017.03.078

Wunder, F., Tinel, H., Kast, R., Geerts, A., Becker, E. M., Kolkhof, P., et al. (2010). Pharmacological characterization of the first potent and selective antagonist at the cysteinyl leukotriene 2 (CysLT(2)) receptor. Br. J. pharmacol. 160, 399-409. doi: $10.1111 / j .1476-5381.2010 .00730 . x$

Xin, W., and Chan, J. R. (2020). Myelin plasticity: sculpting circuits in learning and memory. Nat. Rev. Neurosci. 21, 682-694. doi: 10.1038/s41583-02000379-8

Yeh, J.-H., Wang, K.-C., Kaizaki, A., Lee, J. W., Wei, H.-C., Tucci, M. A., et al. (2021). Pioglitazone ameliorates lipopolysaccharide-induced behavioral impairment, brain inflammation, white matter injury and mitochondrial dysfunction in neonatal rats. Int. J. Mol. Sci. 22:6306. doi: 10.3390/ ijms 22126306 
Zali, A., Arab, L., Ashrafi, F., Mardpour, S., Niknejhadi, M., HedayatiAsl, A. A., et al. (2015). Intrathecal injection of CD133-positive enriched bone marrow progenitor cells in children with cerebral palsy: feasibility and safety. Cytotherapy 17, 232-241. doi: 10.1016/j.jcyt.2014. 10.011

Zhao, C., Deng, Y., Liu, L., Yu, K., Zhang, L., Wang, H., et al. (2016). Dual regulatory switch through interactions of Tcf7l2/Tcf4 with stage-specific partners propels oligodendroglial maturation. Nat. commun. 7:10883. doi: 10. 1038/ncomms 10883

Zhu, B., Luo, R., Jin, P., Li, T., Oak, H. C., Giera, S., et al. (2019). GAIN domainmediated cleavage is required for activation of $\mathrm{G}$ protein-coupled receptor 56 (GPR56) by its natural ligands and a small-molecule agonist. J. Biol. Chem. 294, 19246-19254. doi: 10.1074/jbc.RA119.008234

Zuchero, J. B., Fu, M. M., Sloan, S. A., Ibrahim, A., Olson, A., Zaremba, A., et al. (2015). CNS myelin wrapping is driven by actin disassembly. Dev. Cell 34, 152-167. doi: 10.1016/j.devcel.2015.06.011
Conflict of Interest: The authors declare that the research was conducted in the absence of any commercial or financial relationships that could be construed as a potential conflict of interest.

Publisher's Note: All claims expressed in this article are solely those of the authors and do not necessarily represent those of their affiliated organizations, or those of the publisher, the editors and the reviewers. Any product that may be evaluated in this article, or claim that may be made by its manufacturer, is not guaranteed or endorsed by the publisher.

Copyright (c) 2021 Motavaf and Piao. This is an open-access article distributed under the terms of the Creative Commons Attribution License (CC BY). The use, distribution or reproduction in other forums is permitted, provided the original author(s) and the copyright owner(s) are credited and that the original publication in this journal is cited, in accordance with accepted academic practice. No use, distribution or reproduction is permitted which does not comply with these terms. 